\title{
A study of the relationship between human infection with avian influenza a (H5N6) and environmental avian influenza viruses in Fujian, China
}

Ping Chen ${ }^{1 \dagger}$, Jian-Feng Xie ${ }^{1,2 \dagger}$, Qi Lin², Lin Zhao ${ }^{2}$, Yan-Hua Zhang ${ }^{2}$, Hong-Bin Chen², Yu-Wei Weng ${ }^{1,2}$, Zheng Huang ${ }^{2}$ and Kui-Cheng Zheng ${ }^{1,2^{*}}$

\begin{abstract}
Background: Avian influenza A (H5N6) virus poses a great threat to the human health since it is capable to cross the species barrier and infect humans. Although human infections are believed to largely originate from poultry contaminations, the transmissibility is unclear and only limited information was available on poultry environment contaminations, especially in Fujian Province.

Methods: A total of 4901 environmental samples were collected and tested for Avian Influenza Virus (AIV) from six cities in Fujian Province through the Fujian Influenza Surveillance System from 2013 to 2017. Two patient-related samples were taken from Fujian's first confirmed H5N6 human case and his backyard chicken feces in 2017. Chisquare test or Fisher's exact probability test was used to compare the AIV and the viral subtype positive rates among samples from different Surveillance cities, surveillance sites, sample types, and seasons. Phylogenetic tree analysis and molecular analysis were conducted to track the viral transmission route of the human infection and to map out the evolutions of H5N6 in Fujian.

Results: The overall positive rate of the H5 subtype AlVs was 4.24\% (208/4903). There were distinctive differences $(p<0.05)$ in the positive rates in samples from different cities, sample sites, sample types and seasons. The viruses from the patient and his backyard chicken feces shared high homologies (99.9-100\%) in all the eight gene segments. Phylogenetic trees also showed that these two H5N6 viruses were closely related to each other, and were classified into the same genetic clade 2.3.4.4 with another six H5N6 isolates from the environmental samples. The patient's H5N6 virus carried genes from H6N6, H5N8 and H5N6 viruses originated from different areas. The R294K or N294S substitution was not detected in the neuraminidase (NA). The S31 N substitution in the matrix2 (M2) gene was detected but only in one strain from the environmental samples.

Conclusions: The $\mathrm{H} 5$ subtype of Alvs has started circulating in the poultry environments in Fujian Province. The patient's viral strain originated from the chicken feces in his backyard. Genetic reassortment in H5N6 viruses in Fujian Province was indicated. The H5N6 viruses currently circulating in Fujian Province were still commonly sensitive to Oseltamivir and Zanamivir, but the resistance against Amantadine has emerged.
\end{abstract}

Keywords: Avian influenza a (H5N6) virus, Environmental contamination, Phylogenetic analysis

\footnotetext{
* Correspondence: kingdadi9909@126.com

${ }^{\dagger}$ Ping Chen and Jian-Feng Xie contributed equally to this work.

${ }^{1}$ College of Public Health, Fujian Medical University, No. 88, Jiaotong Road,

Taijiang District, Fuzhou 350000, China

${ }^{2}$ Fujian Center for Disease Control and Prevention, Fujian Provincial Key

Laboratory of Zoonosis Research, Fuzhou 350001, China
}

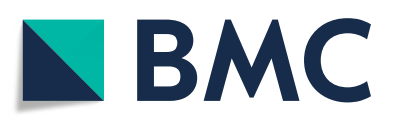

(c) The Author(s). 2019 Open Access This article is distributed under the terms of the Creative Commons Attribution 4.0 International License (http://creativecommons.org/licenses/by/4.0/), which permits unrestricted use, distribution, and

reproduction in any medium, provided you give appropriate credit to the original author(s) and the source, provide a link to the Creative Commons license, and indicate if changes were made. The Creative Commons Public Domain Dedication waiver (http://creativecommons.org/publicdomain/zero/1.0/) applies to the data made available in this article, unless otherwise stated. 


\section{Background}

China's first H5N6 strain was isolated in March 2014 from a domestic duck in Guangdong Province [1]. Since then, the $\mathrm{H} 5$ subtype has gradually become the main cause of the sporadic AIV infections in poultry in southern China [2, 3].

Wild migratory birds and waterfowls are often considered as natural hosts of AIVs. Through their migration, the viruses are transmitted globally $[4,5]$. The $\mathrm{A}(\mathrm{H} 5)$ hemagglutinin(HA) gene from the highly pathogenic avian influenza (HPAI) $\mathrm{A}(\mathrm{H} 5 \mathrm{~N} 1)$ viruses, which were derived from the A/goose/Guangdong/1/96 (gs/GD/96) H5 HA lineage, has continued to rapidly evolve since the most recent update of the H5clade nomenclature by the WHO/ OIE/FAO H5N1 Evolution Working Group [6, 7]. A new HA clade, which has included H5N6, H5N1, H5N8, H5N2 and other subtypes of AIVs since 2014, was identified and named as clade 2.3.4.4 $[6,8,9]$. So far, only the H5N6 viral subtype in the clade 2.3.4.4 has been reported to cross the species barrier and infect humans [10]. In April 2014, the first confirmed human case of avian influenza A (H5N6) virus infection was reported in Sichuan Province, China [11]. As of mid-2017, a total of 17 human H5N6 infections and 7 deaths were reported in China [12]. In December 2017, Fujian Center for Disease Control and Prevention (FJCDC) identified Fujian's first and China's nineteenth human infection of H5N6 virus [13].

Epidemiological investigations have confirmed that most cases of H5N6 human infections had contact with infected poultry [14-16]. Live poultry markets (LPMs) and backyard poultry flocks (BPFs) are two major risk factors for human infections [17, 18]. It had also been noticed that in many provinces, human infections of AIVs decreased gradually after closing LPMs [19].

Therefore, in order to reduce the risk of human H5N6 infection and the impacts of viral circulation in poultry, and also to trace the origin of the human $\mathrm{H} 5 \mathrm{~N} 6$ virus, we collected and analyzed the samples from poultry environments and the human H5N6 virus in Fujian Province, China.

\section{Methods}

\section{Data collection and analysis}

Data for this study were collected through the Fujian Influenza Surveillance System, which has been collecting at least 40 environmental samples monthly from locations such as LPMs, poultry farms, households and slaughter factories in Fuzhou, Xiamen, Quanzhou, Sanming, Nanping and Zhangzhou cities since 2013. Sample types includes surface wipe samples of poultry cage and slaughter or placing board, poultry fecal samples, poultry cleaning sewage samples and poultry drinking water samples. Samples were kept under $4{ }^{\circ} \mathrm{C}$ to $8{ }^{\circ} \mathrm{C}$ and sent to FJCDC within $24 \mathrm{~h}$ for viral detections. Surveillance data from 2013 to 2017 were retrieved and analyzed using SPSS 20.0. The differences of positive detection rates of avian influenza A and the $\mathrm{H} 5$ subtype in different network labs, surveillance sites, sample types, and seasons were tested by chi-square test or Fisher's exact probability test.

\section{Virus isolation and sequencing}

The two case-related samples were injected into 9-to10-day-old specific pathogen-free (SPF) embryonated chicken eggs and inoculated at $37^{\circ} \mathrm{C}$ for $72 \mathrm{~h}$ in a biosafety level 3 laboratory. Hemagglutination assay and hemagglutination inhibition assay of the allantonic fluids were sequentially used for subtype identifications.

Viral RNA was amplified using Qiagen One-Step RTPCR Kit (Qiagen, $\mathrm{GmbH}$ ) with 32 pairs of primers (Additional file 1: Table S1) under the following conditions: $95^{\circ} \mathrm{C}$ for $15 \mathrm{~min}, 50{ }^{\circ} \mathrm{C}$ for $30 \mathrm{~min}, 94^{\circ} \mathrm{C}$ for $2 \mathrm{~min}$, followed by 35 cycles of $94^{\circ} \mathrm{C}$ for $30 \mathrm{~s}, 56^{\circ} \mathrm{C}$ for $30 \mathrm{~s}$ and $72{ }^{\circ} \mathrm{C}$ for $1 \mathrm{~min}$, and finally at $72{ }^{\circ} \mathrm{C}$ for $10 \mathrm{~min}$. PCR products were purified with QIAquick Gel Extraction Kit (Qiagen, GmbH) and sequenced using ABI 3500 genetic analyzer (Life Technologies, Grand Island, NY, USA) following the manufacturer's instructions.

Nucleotide sequencing was performed on an ABI 3500 genetic analyzer (Life Technologies, Grand Island, NY, USA) using the ABI BigDye Terminator v3.1 Cycle Sequencing Kit (Life Technologies) following the manufacturer's instructions. The sequencing primers were M13F (5'-TGTAAAACGACGGCCAGT-3') and M13R (5'CAGGAAACAGCTATG ACC-3'). Sequences were assembled using the SeqMan program of the Lasergene Package (DNASTAR, Inc.; Madison, WI, USA). The genetic sequences of both strains were submitted to the Global Initiative on Sharing Avian Influenza Data (GISAID) (http://platform.gisaid.org/). Full genetic sequences of all six Fujian H5N6 strains from 2016 were retrieved from the China Influenza Virus Genetic Sequence Database and the GISAID EpiFlu Database (isolate ID numbers are presented in Additional file 2: Table S2).

\section{Phylogenetic analysis}

The DNAMAN program (version 6.0) was used for the analysis and alignment of the sequencing data. The phylogenetic trees were performed in MEGA version 6 (The Biodesign Institute, Tempe, AZ, USA) using maximum-likelihood method based on the Tamura-Nei model with 1000 bootstrap replicates [20]. Several typical sequences of other viral subtypes from Asia, especially from the Yangtze River Delta and the Pearl River Delta in China, were also obtained from GISAID and used for constructing phylogenetic trees. (GISAID isolated ID numbers are listed in Additional file 3). The reference sequences were as follows: A/Sichuan/ 26221/2014 (H5N6), A/Guangzhou/39715/2014 (H5N6), A/Guangdong/99710/2014 (H5N6), A/Changsha/1/2014 
Table 1 Surveillance results of environmental AIVs in Fujian Province, during 2013-2017

\begin{tabular}{|c|c|c|c|c|c|c|c|c|}
\hline & & & Influenza A virus & & & H5 subtype & & \\
\hline & & $\begin{array}{l}\text { Number of } \\
\text { samples }\end{array}$ & $\begin{array}{l}\text { Number of positive } \\
(\%)\end{array}$ & $\begin{array}{l}P- \\
\text { value }\end{array}$ & $x^{2}$ & $\begin{array}{l}\text { Number of positive } \\
(\%)\end{array}$ & $\begin{array}{l}P \text { - } \\
\text { value }\end{array}$ & $x^{2}$ \\
\hline $\begin{array}{l}\text { Surveillance } \\
\text { city }\end{array}$ & Fuzhou & 819 & $\begin{array}{l}157 \\
(19.17)\end{array}$ & $<0.001$ & 540.835 & $\begin{array}{l}7 \\
(0.85)\end{array}$ & $<0.001$ & 101.033 \\
\hline & Xiamen & 1060 & $\begin{array}{l}594 \\
(56.04)\end{array}$ & & & $\begin{array}{l}63 \\
(5.94)\end{array}$ & & \\
\hline & Quanzhou & 1234 & $\begin{array}{l}369 \\
(29.90)\end{array}$ & & & $\begin{array}{l}51 \\
(4.13)\end{array}$ & & \\
\hline & Zhangzhou & 589 & $\begin{array}{l}33 \\
(5.60)\end{array}$ & & & $\begin{array}{l}1 \\
(0.17)\end{array}$ & & \\
\hline & Sanming & 600 & $\begin{array}{l}219 \\
(36.50)\end{array}$ & & & $\begin{array}{l}59 \\
(9.83)\end{array}$ & & \\
\hline & Nanping & 601 & $\begin{array}{l}193 \\
(32.11)\end{array}$ & & & $\begin{array}{l}27 \\
(4.49)\end{array}$ & & \\
\hline Sample site & LPMs & 3785 & $\begin{array}{l}1500 \\
(39.63)\end{array}$ & $<.001^{*}$ & & $\begin{array}{l}199 \\
(5.26)\end{array}$ & $<.001^{*}$ & \\
\hline & Poultry farms & 275 & $\begin{array}{l}1 \\
(0.36)\end{array}$ & & & $\begin{array}{l}0 \\
(0.00)\end{array}$ & & \\
\hline & Poultry households & 701 & $\begin{array}{l}48 \\
(6.85)\end{array}$ & & & $\begin{array}{l}4 \\
(0.57)\end{array}$ & & \\
\hline & Poultry slaughter factories & 133 & $\begin{array}{l}16 \\
(12.03)\end{array}$ & & & $\begin{array}{l}5 \\
(3.76)\end{array}$ & & \\
\hline & Others & 9 & $\begin{array}{l}0 \\
(0.00)\end{array}$ & & & $\begin{array}{l}0 \\
(0.00)\end{array}$ & & \\
\hline Sample & Fresh fecal & 1696 & $\begin{array}{l}477 \\
(28.13)\end{array}$ & $\begin{array}{l}< \\
0.001^{*}\end{array}$ & & $\begin{array}{l}55 \\
(3.24)\end{array}$ & $\begin{array}{l}< \\
0.001 *\end{array}$ & \\
\hline & Cage surface & 1245 & $\begin{array}{l}401 \\
(32.21)\end{array}$ & & & $\begin{array}{l}35 \\
(2.81)\end{array}$ & & \\
\hline & Poultry drinking water & 788 & $\begin{array}{l}252 \\
(31.98)\end{array}$ & & & $\begin{array}{l}39 \\
(4.95)\end{array}$ & & \\
\hline & Cleaning poultry sewage & 635 & $\begin{array}{l}249 \\
(39.21)\end{array}$ & & & $\begin{array}{l}38 \\
(5.98)\end{array}$ & & \\
\hline & $\begin{array}{l}\text { Poultry chopping board } \\
\text { surface }\end{array}$ & 535 & $\begin{array}{l}184 \\
(34.39)\end{array}$ & & & $\begin{array}{l}41 \\
(7.66)\end{array}$ & & \\
\hline & Others & 4 & $\begin{array}{l}2 \\
(50.00)\end{array}$ & & & $\begin{array}{l}0 \\
(0.00)\end{array}$ & & \\
\hline Season & Spring & 1448 & $\begin{array}{l}555 \\
(38.33)\end{array}$ & $<0.001$ & 90.916 & $\begin{array}{l}78 \\
(5.39)\end{array}$ & $<0.001$ & 48.174 \\
\hline & Summer & 1060 & $\begin{array}{l}284 \\
(26.79)\end{array}$ & & & $\begin{array}{l}20 \\
(1.89)\end{array}$ & & \\
\hline & Autumn & 975 & $\begin{array}{l}218 \\
(22.36)\end{array}$ & & & $\begin{array}{l}19 \\
(1.95)\end{array}$ & & \\
\hline & Winter & 1420 & $\begin{array}{l}508 \\
(35.77)\end{array}$ & & & $\begin{array}{l}91 \\
(6.41)\end{array}$ & & \\
\hline & Total & 4903 & $\begin{array}{l}1565 \\
(31.92)\end{array}$ & & & $\begin{array}{l}208 \\
(4.24)\end{array}$ & & \\
\hline
\end{tabular}

${ }^{*} P$ value counted by Fisher's exact probability

(H5N6), A/Guangdong/ZQ874/2015 (H5N6), A/Shenzhen/1/2015 (H5N6), A/Anhui/33163/2016 (H5N6), and A/Hubei/29578/2016 (H5N6). GISAID isolate ID of the viruses above were listed in Additional file 2: Table S2.

\section{Results}

Statistical analysis of surveillance samples

The positive detection rates of influenza A virus and the H5 subtype were $31.92 \%(1565 / 4903)$ and $4.24 \%$ 
(208/4903), respectively. There were statistical differences in the positive rates of influenza $\mathrm{A}$ virus and the H5 subtype in different cities, sample sites, samples types and seasons $(p<0.05)$. The highest positive rates of the H5 subtype were observed in Sanming city (9.83\%), LPMs (5.26\%), and the wipe samples of poultry chopping board (7.66\%). The positive rates of $\mathrm{H} 5$ subtype were at peak in winter and spring (Table 1). The subtypes in the other positive samples were shown in Additional file 1: TableS1.

\section{Phylogenetic analysis of the H5N6 viruses}

Viral isolates from the confirmed case and his courtyard chicken feces shared 99.9 to $100.0 \%$ nucleotide sequence identities in eight gene segments (Table 2). This result revealed that the human case was infected through the close contact with his contaminated courtyard poultry environment.

Phylogenetic tree analysis also confirmed that the eight gene segments of the patient strain (A/Fujian-Sanyuan/ 21099/2017) were closely related to the courtyard chicken feces strain (A/environment/fujiansanyuan/08/ 2017). Their PA genes were both clustered into the $\mathrm{H}_{\mathrm{X}} \mathrm{N} 6$ viruses and were the closest to the H6N6 strain of A/Muscovy duck/Vietnam/LBM 811/2015. Their polymerase basic 2 (PB2), polymerase basic 1 (PB1), HA, matrix protein (MP) and nonstructural (NS) genes appeared to be derived from an H5N8 virus isolated from a black swan in Hubei Province, China (A/Cygnus atratus/Hubei/HF-1/2016). Their NA and nucleoprotein (NP) gene segments were in the same cluster as the H5N6 viruses that were circulating in Fujian Province during 2016 (Additional file 1 and Fig. 1). These findings demonstrated that A/Fujian-Sanyuan/21099/2017, a triple reassortant virus, had reasserted from H6N6, $\mathrm{H} 5 \mathrm{~N} 8$, and $\mathrm{H} 5 \mathrm{~N} 6$ viruses. According to the WHO nomenclature system [21], the human H5N6 virus and the other 7 environmental $\mathrm{H} 5 \mathrm{~N} 6$ isolates from this study were clustered into clade 2.3.4.4, same as the other human H5N6 strains from different provinces. However, the human H5N6 strain in Fujian had a genetic distance from the other human strains. In addition, the human H5N6 strain in this study and the human H5N1 strain isolated in 2005 in Fujian Province both belonged to clade 2.3.4, however in two different sub-branches. These results showed that the H5 subtype in Fujian Province has been constantly evolving, and the human H5N6 virus in Fujian Province may be a novel reassortant virus.

\section{Molecular characteristics of the H5N6 viruses}

The key amino acid mutations had increased the viral mammalian transmissibility, virulence in mammals and antiviral resistance in the human strain and the other 7 environmental strains of H5N6 viruses (Table 3).The HA of all eight virus strains showed a multiple basic amino acid motif of RERRRKR $\downarrow G L$, indicating high pathogenicity in poultry. However, the Q226L and G228S mutations that may enhance the risk of human infection were not identified at the 210-loop in the HA proteins in all eight virus strains. The previously reported deletion of the five amino acids at the position 69 to 73 in the stalk region of NA residue was not observed in the eight H5N6 viruses from Fujian. Neither R294K nor N294S substitution was detected in the NA genes of all the eight H5N6 viruses, indicating a general sensitivity to Oseltamivir and Zanamivir antiviral drugs. However, the $\mathrm{S} 31 \mathrm{~N}$ substitution in the M2 gene was detected in one strain of A/Environment/Fujian/28681/ 2016. Other mutations that have been shown to increase virulence in mice, such as L89 V, G309D, T339K, R477G and I495V in PB2, P42S in NS1, N30D and T215A in M1, were also detected.

\section{Discussion}

Since the H5N1 virus was first identified in Guangdong Province, China, 1996, this high pathogenic H5 subtype of AIVs has been continually detected in wild birds and domestic poultry environments [34]. The H5N1 virus has gradually evolved into novel reassortant $\mathrm{H} 5 \mathrm{Nx}$

Table 2 Homology analysis between human H5N6 virus and H5N6 viruses from environments shed by infected poultry

\begin{tabular}{|c|c|c|c|c|c|c|c|c|}
\hline \multirow[t]{2}{*}{ Isolates } & \multicolumn{8}{|c|}{ A/Fujian-Sanyuan/21099/2017 (Identities \%) } \\
\hline & PB2 & PB1 & PA & $\mathrm{HA}$ & NP & NA & MP & NS \\
\hline A/Environment/Fujian/05324/2016 & 88.4 & 88.1 & 91.6 & 93.9 & 98.4 & 96.3 & 90.5 & 90.4 \\
\hline A/Environment/Fujian/05326/2016 & 85.1 & 90.1 & 91.6 & 94.1 & 97.2 & 98.2 & 90.1 & 90.4 \\
\hline A/Environment/Fujian/09991/2016 & 85.4 & 87.2 & 91.9 & 94.1 & 98.0 & 98.5 & 90.2 & 91.2 \\
\hline A/Environment/Fujian/28681/2016 & 88.8 & 88.0 & 87.8 & 94.0 & 91.8 & 95.7 & 87.6 & 87.7 \\
\hline A/Environment/Fujian/28686/2016 & 85.4 & 87.2 & 91.9 & 94.0 & 98.1 & 98.5 & 90.2 & 91.2 \\
\hline A/Environment/Fujian/52356/2016 & 88.5 & 88.1 & 91.5 & 93.5 & 97.8 & 95.9 & 90.3 & 89.8 \\
\hline A/Environment/Fujiansanyuan/08/2017 & 100.0 & 100.0 & 99.9 & 100.0 & 99.9 & 99.9 & 100 & 100.0 \\
\hline
\end{tabular}




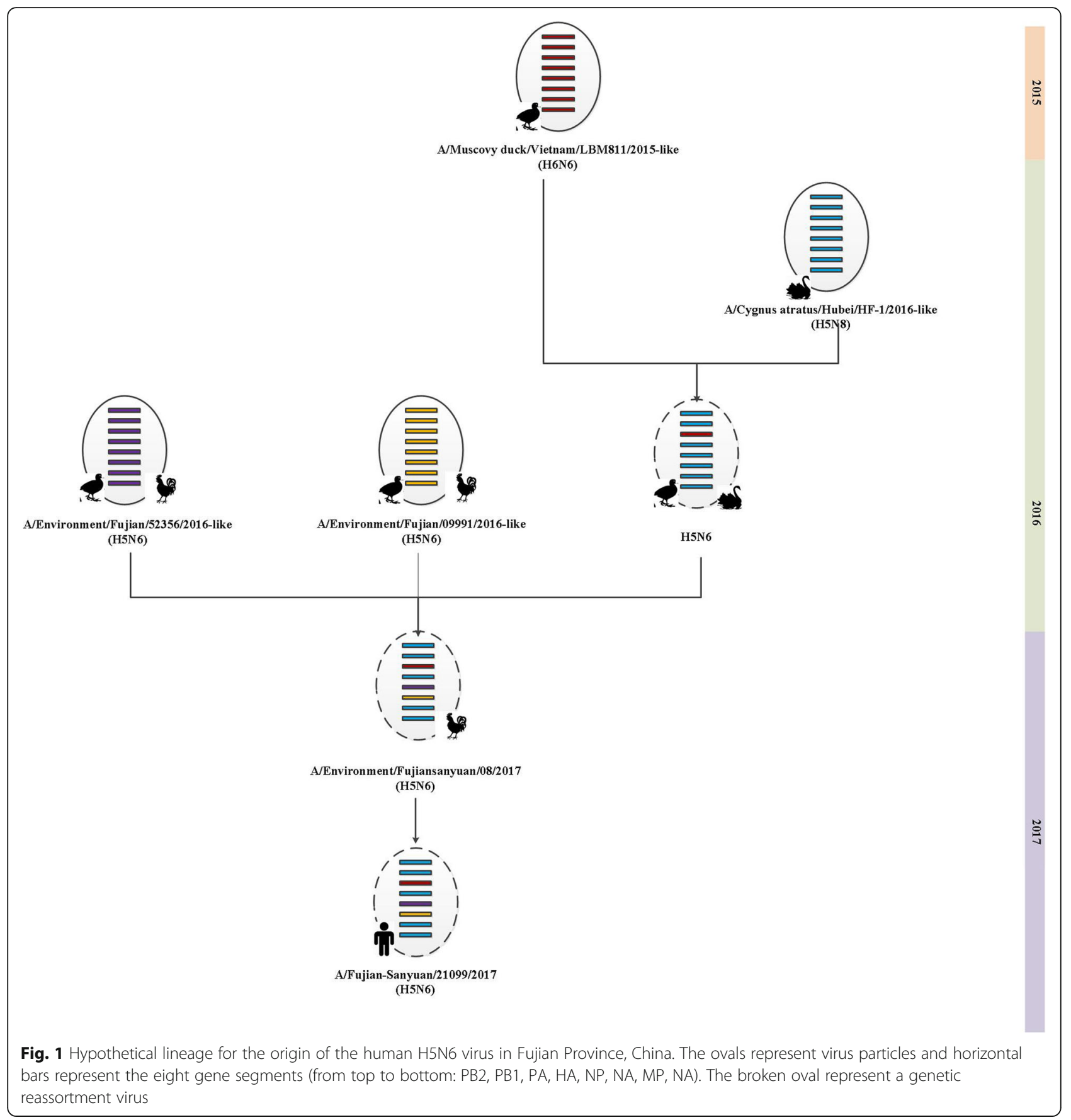

viruses of different NA subtypes since 2008 [35]. In later years, the H5N6 virus has spread among poultry in the southern and western China [2]. Poultry outbreaks of H5N6 were recorded in China, Laos and Vietnam in 2014 [36]. In China, LPMs played a key role in amplifying and disseminating AIVs through poultry market chains, where the reassortment and the emergence of novel viruses often take place [15]. The positive rate of H5 subtype in LPMs in Fujian Province was 5.26\%, which was significantly higher than the other sample sites. Our data also showed that, during 2013 to 2017, the H5 subtype of AIVs had been circulating in the 6 surveillance cities in Fujian Province, with peak positive detection rates in the winter and spring seasons. These seasonal peaks were consistent with the seasonal trend of human avian influenza $\mathrm{A}$ infections [37]. Attentions need to be paid to the prevention and control of avian influenza in areas with high positive rates of the $\mathrm{H} 5$ subtype in winters and springsand in the poultry environment, to reduce viral 
Table 3 Molecular analysis of H5N6 virus isolates in Fujian Province, China

\begin{tabular}{|c|c|c|c|c|c|c|c|c|c|c|}
\hline $\begin{array}{l}\text { Viral } \\
\text { Protein }\end{array}$ & Mutations\# & Virus $^{1}$ & Virus $^{2}$ & Virus $^{3}$ & Virus $^{4}$ & Virus $^{5}$ & Virus $^{6}$ & Virus $^{7}$ & Virus $^{8}$ & Function \\
\hline \multirow[t]{3}{*}{$\mathrm{HA}$} & Q226L* & Q & Q & Q & Q & Q & Q & Q & Q & Increased a2,6-SA recognition [22] \\
\hline & G2285* & G & G & G & G & G & G & G & G & Increased a2,6-SA recognition [22] \\
\hline & Cleavage site & $\begin{array}{l}\text { RERRR } \\
\text { KR\GL }\end{array}$ & $\begin{array}{l}\text { RERRR } \\
\mathrm{KR} \downarrow \mathrm{GL}\end{array}$ & 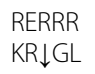 & $\begin{array}{l}\text { RERRR } \\
\mathrm{KR} \downarrow \mathrm{GL}\end{array}$ & 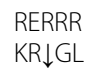 & $\begin{array}{l}\text { RERRR } \\
\mathrm{KR} \downarrow \mathrm{GL}\end{array}$ & 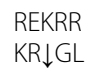 & $\begin{array}{l}\text { RERRR } \\
\text { KR\GL }\end{array}$ & Enhanced pathogenic effects in poultry [23] \\
\hline \multirow[t]{2}{*}{ NA } & $\begin{array}{l}69- \\
73 \text { deletion }\end{array}$ & No & No & No & No & No & No & No & No & Increased virulence in mice [24] \\
\hline & R294K/N294S & $\mathrm{R}$ & $\mathrm{R}$ & $\mathrm{R}$ & $\mathrm{R}$ & $\mathrm{R}$ & $\mathrm{R}$ & $\mathrm{R}$ & $\mathrm{N}$ & Oseltamivir and zanamivir resistance [25] \\
\hline \multirow[t]{7}{*}{ PB2 } & L89V & V & V & V & V & V & V & V & V & Enhanced pathogenicity in mice [26] \\
\hline & G309D & $\mathrm{D}$ & $\mathrm{D}$ & D & $\mathrm{D}$ & $\mathrm{D}$ & $\mathrm{D}$ & $\mathrm{D}$ & $\mathrm{D}$ & Increased virulence and replication in mice [27] \\
\hline & T339K & K & K & K & K & K & K & K & K & Increased virulence and replication in mice [27] \\
\hline & R477G & G & G & G & G & G & G & G & G & Increased virulence and replication in mice [27] \\
\hline & $1495 \mathrm{~V}$ & V & V & V & V & V & V & V & V & Increased virulence and replication in mice [27] \\
\hline & E627K & $\mathrm{E}$ & $\mathrm{E}$ & E & $\mathrm{E}$ & E & E & $\mathrm{E}$ & $\mathrm{E}$ & Mammalian host adaptation [28] \\
\hline & D701N & $\mathrm{D}$ & $\mathrm{D}$ & $\mathrm{D}$ & $\mathrm{D}$ & $\mathrm{D}$ & $\mathrm{D}$ & $\mathrm{D}$ & $\mathrm{D}$ & Enhanced transmission in guinea pigs [29] \\
\hline \multirow[t]{2}{*}{ PB1 } & H99Y & $\mathrm{H}$ & $\mathrm{H}$ & $\mathrm{H}$ & $\mathrm{H}$ & $\mathrm{H}$ & $\mathrm{H}$ & $\mathrm{H}$ & $\mathrm{H}$ & Enhanced H5 virus transmissible among ferrets [26] \\
\hline & I368V & । & I & I & V & । & I & I & I & Enhanced H5 virus transmissible among ferrets [26] \\
\hline \multirow[t]{3}{*}{ NS1 } & P42S & S & S & S & S & S & S & S & S & Increased virulence in mice [30] \\
\hline & D92E & $\mathrm{E}$ & E & E & $\mathrm{D}$ & E & $\mathrm{E}$ & $\mathrm{D}$ & $\mathrm{D}$ & Increased virulence in mice and pigs [27] \\
\hline & $\begin{array}{l}\text { 218- } \\
\text { 230deletion }\end{array}$ & Yes & Yes & Yes & Yes & Yes & Yes & No & No & $\begin{array}{l}\text { Lack of PDZ domain binding motif:decreased virulence } \\
\text { in mice [31] }\end{array}$ \\
\hline \multirow[t]{2}{*}{ M1 } & N30D & D & $\mathrm{D}$ & D & $\mathrm{D}$ & $\mathrm{D}$ & $\mathrm{D}$ & $\mathrm{D}$ & $\mathrm{D}$ & Increased virulence in mice [32] \\
\hline & T215A & A & A & A & A & A & A & $A$ & A & Increased virulence in mice [32] \\
\hline M2 & S31N & S & S & S & $\mathrm{N}$ & $S$ & $S$ & $S$ & $S$ & Amantadine resistance [33] \\
\hline
\end{tabular}

reassortments and therefore viral transmissibility in mammals.

The H5N6 viral isolates from the first human case in 2014 carried the same internal genes as the H5N1 virus identified in 2013 [3]. In the same year, Korea reported the $\mathrm{H} 5 \mathrm{~N} 8$ subtype of avian influenza virus [38], which subsequently spread across East Asia, North America and Europe [39]. The H5N8 and H5N6 both belong to clade 2.3.4.4 [40]. However, different from the H5N8 viruses, the circulation of H5N6 viruses is limited in China, Laos, and Vietnam [10]. In Fujian Province, the recently circulating H5N6 (clade 2.3.4.4) and the previously circulating H5N1 (clade 2.3.4) isolates in 2005 were classified into different clusters by the phylogenetic analysis of the HA genes, indicating a transition of the dominating virus in poultry circulation.

Influenza viruses are carried by migratory waterfowl and therefore spread globally along the avian flyways during migration [41]. $\mathrm{H} 5 \mathrm{~N} 6$ is also circulated among migratory birds [42]. During migration seasons, the risk of geographical spread of AIVs is elevated. The shallow lakes connected to the Yangtze River and the Pearl River have copious biological resources and serve as important stopover sites for large flocks of migratory birds. Fujian Province, located between the Yangtze River and the Pearl River, is an important stopover point along the East Asian-Australasian Flyway, inhabiting large and various flocks of globally migratory birds [43, 44]. Genetic reassortments and viral evolutions are constantly occurring in Fujian Province because of its geological location and its dense and scaled poultry industries. Phylogenetic analysis showed that the environmental $\mathrm{H} 5 \mathrm{~N} 6$ viruses were closely related to the H5N6, H5N8, and H6N6 viruses that have been circulating among poultry in China. It was therefore speculated that the viruses analyzed in this study originate from poultry, not wild birds. Furthermore, the human H5N6 strain in this study had genetic distance from the other human strains from different provinces in recent years. It was concluded that the human H5N6 strain in this study may be a novel reassortant virus.

The H5N6 viruses in this study were considered highly pathogenic in poultry due to the amino acids at the HA cleavage site. The affinities of the influenza virus to different sialyl-sugar structures are important determinants of rang and pathogenicity in the viral host [26]. The $\alpha-2,6$ sialyl 
glycan binds with human influenza viruses, but the $\alpha-2,3$ sialyl glycan binds with avian viruses [45]. The Q226L and G228S mutations in HA were reported to bind with the $\alpha$ 2,6 sialyl glycan receptors. In this study, we didn't find these mutations that could increase viral adaption to human hosts. The 69-73 amino acids deletion in NA were observed to enhance virulence in mice [24], and may be associated with the viral adaptation and transmission in poultry $[26,46]$. However this deletion was not observed in the H5N6 virus strains in our study. Based on the amino acid sequences of A/Fujian-Sanyuan/21099/2017, the human strain was still sensitive to Oseltamivir and Zanamivir. One of environmental H5N6 strains was resistant to Amantadine. Other virulence markers were found in PB2, PB1, NS1 and M1. However, these mutations were only studied in animals, and their effects on the virulence in human hosts require further research.

Our study has several strengths, including large environmental sample size, viral isolated from Fujian's first confirmed H5N6 human case and his courtyard chicken feces. However, this study also has some limitations, for example, the signs and symptoms and mortality rates among poultry were not collected.

\section{Conclusions}

The results of this study indicated that in Fujian Province, the clade 2.3.4.4 of the H5 subtype had become the main circulating AIVs in poultry environments. The patient with H5N6 infection was most likely to contract the virus from contaminated poultry environment. The human strain had genetic reassortment with $\mathrm{H} 6 \mathrm{~N} 6, \mathrm{H} 5 \mathrm{~N} 8$, and $\mathrm{H} 5 \mathrm{~N} 6$ viruses. It was still sensitive to Oseltamivir and Zanamivir. Although there has been no outbreak of human infection with H5N6 in Fujian Province, it is of great importance to continue and strengthen the surveillance of the $\mathrm{H} 5 \mathrm{Nx}$ virus in poultry environment to monitor the spread and evolution of the virus.

\section{Additional files}

Additional file 1: Table S1. Composition of subtypes of AIVs positive specimens in Fujian Province, during 2013-2017. H5 + H7: Both the H5 and $\mathrm{H} 7$ subtype influenza virus nucleic acids were detected in the same sample and other subtypes and so on. (DOCX $18 \mathrm{~kb}$ )

Additional file 2: Table S2. The GISAID isolate ID of H5N6 viruses. (DOCX $16 \mathrm{~kb}$ )

Additional file 3: Phylogenetic analysis of the $\mathrm{H} 5 \mathrm{~N} 6$ viruses isolated in Fujian Province. (In red Triangle) Viral strains of human infection with avian influenza $\mathrm{A}(\mathrm{H} 5 \mathrm{~N} 6)$ virus in Fujian Province. (In green Square) Viral strains of human $\mathrm{H} 5 \mathrm{~N} 6$ viruses. (In red Circle) Viral strains of $\mathrm{H} 5 \mathrm{~N} 6$ viruses isolated from environment sample in Fujian Province. (DOC 415 kb)

\section{Abbreviations}

AIV: Avian Influenza Virus; BPFs: Backyard poultry flocks; FJCDC: Fujian Center for Disease Control and Prevention; GISAID: Global Initiative on Sharing Avian Influenza Data; HA: Hemagglutinin; HPAl: Highly pathogenic avian influenza; LPMs: Live poultry markets; MP: Matrix protein; NA: Neuraminidase;
NP: Nucleoprotein; NS: Nonstructural proteins; PA: Acidic polymerase; PB1: Basic polymerase 1; PB2: Basic polymerase 2

\section{Acknowledgements}

We are grateful to the authors and their laboratories for sharing the influenza virus sequences in the GISAID EpiFlu database, and send our sincere acknowledgement to the staff of the Centers for Disease Control and Prevention of Fuzhou District, Xiamen District, Quanzhou District, Zhangzhou District, Sanming District and Nanping District, Fujian, China for their assistance in collecting samples.

\section{Authors' contributions}

PC, JF-X designed the study; PC, QL, LZ, YH-Z and HB-C carried out laboratory experiments, $P C$ performed phylogenetic analyses and wrote the original manuscript; JF-X and $Z \mathrm{ZH}$ revised the manuscript; $Y \mathrm{~W}-\mathrm{W}$ and $\mathrm{KC}-\mathrm{Z}$ supervised the study; KC-Z gave approval for its publication. All the authors read and approved the final version of the manuscript.

\section{Funding}

This work was supported by the National Science and Technology Major Project (2017ZX10103008), the Natural Science Foundation of Fujian Province (2015 J01294) and the Youth Backbone Talents Cultivation Program of Health System in Fujian Province (2015-ZQN-ZD-10). The funders had no roles in the design of the study and collection, analysis, and interpretation of data and in writing the manuscript.

Availability of data and materials

The dataset used and analyzed in this study are stored in GISAID and FJ

CDC. The datasets are available upon reasonable requests to the

corresponding author

\section{Ethics approval and consent to participate}

The collection of environmental samples was conducted for the control and management of national notifiable diseases, no human or animal researches were conducted, and therefore ethical approval was not required.

\section{Consent for publication}

Not applicable.

\section{Competing interests}

The authors declare that they have no competing interests.

Received: 27 February 2019 Accepted: 29 May 2019

Published online: 02 September 2019

\section{References}

1. Shen H, Wu B, Chen Y, Bi Y, Xie Q. Influenza a(H5N6) virus Reassortant, southern China, 2014. Emerg Infect Dis. 2015;21:1261-2.

2. Garcia M, Suarez DL, Crawford JM, Latimer JW, Slemons RD, Swayne DE, et al. Evolution of $\mathrm{H} 5$ subtype avian influenza a viruses in North America. Virus Res. 1997:51:115-24.

3. Bi Y, Chen Q, Wang Q, Chen J, Jin T, Wong G, et al. Genesis, evolution and prevalence of H5N6 avian influenza viruses in China. Cell Host Microbe. 2016;20:810-21.

4. Olsen B, Munster VJ, Wallensten A, Waldenstrom J, Osterhaus AD, Fouchier RA. Global patterns of influenza a virus in wild birds. Science. 2006;312:384-8.

5. Lei F, Shi W. Prospective of genomics in revealing transmission, Reassortment and evolution of wildlife-borne avian influenza a (H5N1) viruses. Curr Genomics. 2011:12:466-74.

6. Smith GJ, Donis RO. Nomenclature updates resulting from the evolution of avian influenza a(H5) virus clades 2.1.3.2a, 2.2.1, and 2.3.4 during 2013-2014. Influenza Other Respir Viruses. 2015;9:271-6.

7. World Health Organization, World Organisation for Animal Health, Food and Agriculture Organization (WHO/OIE/FAO) H5N1 Evolution Working Group. Revised and updated nomenclature for highly pathogenic avian influenza A (H5N1) viruses. Influenza Other Respir Viruses. 2014:8:384-8.

8. Okamatsu M, Ozawa M, Soda K, Takakuwa H, Haga A, Hiono T, et al Characterization of highly pathogenic avian influenza virus a(H5N6), Japan November 2016. Emerg Infect Dis. 2017;23:691-5. 
9. Wu H, Peng $X, X u L$, Jin $C$, Cheng $L$, Lu X, et al. Characterization of a novel highly pathogenic $\mathrm{H} 5 \mathrm{~N} 2$ avian influenza virus isolated from a duck in eastern China. Arch Virol. 2014;159:3377-83.

10. Herfst S, Mok C, van den Brand J, van der Vliet S, Rosu ME, Spronken Ml, et al. Human clade 2.3.4.4 a/H5N6 influenza virus lacks mammalian adaptation markers and does not transmit via the airborne route between ferrets. Msphere. 2018;3(1).

11. Zhang R, Chen T, Ou X, Liu R, Yang Y, Ye W, et al. Clinical, epidemiological and virological characteristics of the first detected human case of avian influenza a(H5N6) virus. Infect Genet Evol. 2016;40:236-42.

12. Si YJ, Lee IW, Kim EH, Kim YI, Kwon HI, Park SJ, et al. Genetic characterisation of novel, highly pathogenic avian influenza (HPAl) H5N6 viruses isolated in birds, South Korea, November 2016. Euro Surveill. 2017;22(1).

13. World Health Organization.Influenza at human-animal interface[EB/OL]. http:// www.who.int/influenza/human_animal_interface/Influenza_Summary_IRA_ HA_interface_25_01_2018_FINAL.pdf?ua=1. Accessed 9 Apr 2018.

14. Luo S, Xie Z, Xie Z, Xie L, Huang L, Huang J, et al. Surveillance of live poultry Markets for low Pathogenic Avian Influenza Viruses in Guangxi Province, southern China, from 2012-2015. Sci Rep. 2017;7:17577.

15. Chen LJ, Lin XD, Guo WP, Tian JH, Wang W, Ying XH, et al. Diversity and evolution of avian influenza viruses in live poultry markets, free-range poultry and wild wetland birds in China. J Gen Virol. 2016;97:844-54.

16. Shimizu K, Wulandari L, Poetranto ED, Setyoningrum RA, Yudhawati R, Sholikhah A, et al. Seroevidence for a high prevalence of subclinical infection with avian influenza a(H5N1) virus among Workers in a LivePoultry Market in Indonesia. J Infect Dis. 2016;214:1929-36.

17. Ly S, Vong S, Cavailler P, Mumford E, Mey C, Rith S, et al. Environmental contamination and risk factors for transmission of highly pathogenic avian influenza a(H5N1) to humans, Cambodia, 2006-2010. BMC Infect Dis. 2016;16:631

18. Liu B, Havers F, Chen E, Yuan Z, Yuan H, Ou J, et al. Risk factors for influenza a(H7N9) disease--China. 2013 Clin Infect Dis. 2014;59:787-94.

19. Wang XX, Cheng W, Yu Z, Liu SL, Mao HY, Chen EF. Risk factors for avian influenza virus in backyard poultry flocks and environments in Zhejiang Province, China: a cross-sectional study. Infect Dis Poverty. 2018;7:65.

20. Kumar S, Stecher G, Tamura K. MEGA7: molecular evolutionary genetics analysis version 7.0 for bigger datasets. Mol Biol Evol. 2016;33:1870-4.

21. WHO Human-Animal Interface web page http://www.who.int/influenza/ human animal interface/en/. Accessed 23 Jan 2018.

22. Srinivasan K, Raman R, Jayaraman A, Viswanathan K, Sasisekharan R. Quantitative description of glycan-receptor binding of influenza a virus H7 hemagglutinin. PLoS One. 2013;8:e49597.

23. Senne DA, Panigrahy B, Kawaoka Y, Pearson JE, Suss J, Lipkind M, et al Survey of the hemagglutinin $(\mathrm{HA})$ cleavage site sequence of $\mathrm{H} 5$ and $\mathrm{H} 7$ avian influenza viruses: amino acid sequence at the HA cleavage site as a marker of pathogenicity potential. Avian Dis. 1996;40:425-37.

24. McKimm-Breschkin JL, Sahasrabudhe A, Blick TJ, McDonald M, Colman PM, Hart GJ, et al. Mutations in a conserved residue in the influenza virus neuraminidase active site decreases sensitivity to Neu5Ac2en-derived inhibitors. J Virol. 1998;72:2456-62.

25. Yu Z, Gao X, Wang T, Li Y, Li Y, Xu Y, et al. Fatal H5N6 avian influenza virus infection in a domestic cat and wild birds in China. Sci Rep. 2015; 5:10704.

26. Gao R, Cao B, Hu Y, Feng Z, Wang D, Hu W, et al. Human infection with a novel avian-origin influenza a (H7N9) virus. N Engl J Med. 2013;368:1888-97.

27. Shen YY, Ke CW, Li Q, Yuan RY, Xiang D, Jia WX, et al. Novel Reassortant avian influenza a(H5N6) viruses in humans, Guangdong, China, 2015. Emerg Infect Dis. 2016;22:1507-9.

28. Hatta M, Gao P, Halfmann P, Kawaoka Y. Molecular basis for high virulence of Hong Kong H5N1 influenza a viruses. Science. 2001;293:1840-2.

29. Chen H, Yuan H, Gao R, Zhang J, Wang D, Xiong Y, et al. Clinical and epidemiological characteristics of a fatal case of avian influenza a H10N8 virus infection: a descriptive study. Lancet. 2014:383:714-21.

30. Jiao P, Tian G, Li Y, Deng G, Jiang Y, Liu C, et al. A single-amino-acid substitution in the NS1 protein changes the pathogenicity of H5N1 avian influenza viruses in mice. J Virol. 2008;82:1146-54.

31. Jackson D, Hossain MJ, Hickman D, Perez DR, Lamb RA. A new influenza virus virulence determinant: the NS1 protein four C-terminal residues modulate pathogenicity. Proc Natl Acad Sci U S A. 2008;105:4381-6.

32. Fan S, Deng G, Song J, Tian G, Suo Y, Jiang Y, et al. Two amino acid residues in the matrix protein $\mathrm{M} 1$ contribute to the virulence difference of H5N1 avian influenza viruses in mice. Virology. 2009;384:28-32.
33. Pinto $L H$, Holsinger $L$, Lamb RA. Influenza virus $M 2$ protein has ion channel activity. Cell. 1992;69:517-28.

34. Richard M, Herfst S, van den Brand JM, Lexmond P, Bestebroer TM, Rimmelzwaan GF, et al. Low virulence and lack of airborne transmission of the Dutch highly pathogenic avian influenza virus H5N8 in ferrets. PLoS One. 2015;10:e129827.

35. Yang H, Carney PJ, Mishin VP, Guo Z, Chang JC, Wentworth DE, et al. Molecular characterizations of surface proteins Hemagglutinin and neuraminidase from recent H5Nx avian influenza viruses. J Virol. 2016;90:5770-84.

36. Qi X, Cui L, Yu H, Ge Y, Tang F. Whole-genome sequence of a Reassortant H5N6 avian influenza virus isolated from a live poultry market in China, 2013. Genome Announc. 2014;2(5)

37. Wu H, Wang X, Xue M, Xue M, Wu C, Lu Q, et al. Spatial characteristics and the epidemiology of human infections with avian influenza a(H7N9) virus in five waves from 2013 to 2017 in Zhejiang Province, China. PLoS One. 2017;12:e180763.

38. Lee YJ, Kang HM, Lee EK, Song BM, Jeong J, Kwon YK, et al. Novel reassortant influenza a(H5N8) viruses, South Korea, 2014. Emerg Infect Dis. 2014;20:1087-9.

39. Bouwstra RJ, Koch G, Heutink R, Harders F, van der Spek A, Elbers AR, et al. Phylogenetic analysis of highly pathogenic avian influenza a $(\mathrm{H} 5 \mathrm{~N} 8)$ virus outbreak strains provides evidence for four separate introductions and one between-poultry farm transmission in the Netherlands, November 2014. Euro Surveill. 2015;20(6).

40. Gu M, Liu W, Cao Y, Peng D, Wang X, Wan H, et al. Novel reassortant highly pathogenic avian influenza (H5N5) viruses in domestic ducks, China. Emerg Infect Dis. 2011;17:1060-3.

41. Verhagen $\mathrm{JH}$, Herfst $\mathrm{S}$, Fouchier RA. Infectious disease. How a virus travels the world. Science. 2015;347:616-7.

42. Bi Y, Liu H, Xiong C, Di L, Shi W, Li M, et al. Novel avian influenza a (H5N6) viruses isolated in migratory waterfowl before the first human case reported in China, 2014. Sci Rep. 2016;6:29888.

43. Yong DL, Jain A, Liu Y, labal M, Choi CY, Crockford NJ, et al. Challenges and opportunities for transboundary conservation of migratory birds in the east Asian-Australasian flyway. Conserv Biol. 2018;32:740-3.

44. Langstaff IG, McKenzie JS, Stanislawek WL, Reed CE, Poland R, Cork SC Surveillance for highly pathogenic avian influenza in migratory shorebirds at the terminus of the east Asian-Australasian flyway. N Z Vet J. 2009;57:160-5.

45. Ito T, Kawaoka Y. Host-range barrier of influenza a viruses. Vet Microbiol. 2000;74:71-5

46. Li J, Zu DH, Cardona CJ, Miller J, Carpenter TE. Emergence and genetic variation of neuraminidase stalk deletions in avian influenza viruses. PLoS One. $2011 ; 6:$ :e14722.

\section{Publisher's Note}

Springer Nature remains neutral with regard to jurisdictional claims in published maps and institutional affiliations.

Ready to submit your research? Choose BMC and benefit from:

- fast, convenient online submission

- thorough peer review by experienced researchers in your field

- rapid publication on acceptance

- support for research data, including large and complex data types

- gold Open Access which fosters wider collaboration and increased citations

- maximum visibility for your research: over $100 \mathrm{M}$ website views per year

At $\mathrm{BMC}$, research is always in progress.

Learn more biomedcentral.com/submissions 